\title{
PROJECT MANAGEMENT IN EXECUTIVE AUTHORITIES OF THE RUSSIAN FEDERATION SUBJECTS: THE PROFESSIONAL STAFFING CONSIDERATIONS
}

\author{
Irina A. ARTASHINA ${ }^{\mathrm{a},}$, Aleksandr N. SHTEFAN ${ }^{\mathrm{b}}$
}

\author{
a Nizhny Novgorod Institute of Management, Branch of RANEPA, \\ Nizhny Novgorod, Russian Federation \\ artashina@mail.ru \\ ORCID: not available \\ ${ }^{\mathrm{b}}$ Nizhny Novgorod Institute of Management, Branch of RANEPA, \\ Nizhny Novgorod, Russian Federation \\ ashtefan2601@ya.ru \\ ORCID: not available \\ - Corresponding author
}

\section{Article history: \\ Received 23 April 2019 \\ Received in revised form 16 May 2019 \\ Accepted 29 May 2019 \\ Available online \\ 15 July 2019}

JEL classification: R11, R58

Keywords: project management, regional project, project management system, executive authorities, Federal subjects of Russia

\begin{abstract}
Subject This article deals with the issues of implementation of a project-based approach in the activities of the authorities and the problems of staff efficiency.

Objectives The article aims to identify the specifics of project approach application within the public sector framework.

Methods For the study, we used the logical and systems approaches, sampling, grouping, generalization, comparison, content analysis, and the graphical and tabular data visualization methods.
\end{abstract}

Results The article presents a brief analytical overview of the open data posted on the official websites of the governments of the Federal subjects of Russia and an analysis of the project-based approach specifics in terms of talent acquisition.

Conclusions The article concludes that in the modern system of management of the executive branch of the subjects of the Russian Federation, there are imperfections of personnel policy, defined as errors of application of a comprehensive approach to the requirements concerning the vocational education. This circumstance creates certain conditions and prerequisites for increasing the risks of the mechanism of regional projects implementation. In this regard, it is advisable to consider the need for enhanced project management training of the RF subject government employees, who are part of the project teams.

Please cite this article as: Artashina I.A., Shtefan A.N. Project Management in Executive Authorities of the Russian Federation Subjects: The Professional Staffing Considerations. Regional Economics: Theory and Practice, 2019, vol. 17, iss. 7, pp. 1257-1266. https://doi.org/10.24891/re.17.7.1257

\section{Introduction}

Being proactive worldwide, Russia is currently facing challenges of political and socio-economic nature. Therefore, the Russian regions need to objectively assess their advantages in order to generate resources and effectively use their own management potential to meet strategic development priorities. Various management mechanisms, including methods of searching, using and improving the competitiveness of the region's internal reserves, regional development mobilization factors, and effective management tools and practices are becoming driving forces of crisis management.

The latter include the project management.

To improve the effectiveness of the Federal executive authorities and executive authorities of the Federal subjects of Russia to achieve the goals and objectives set by the Ministry of Economic Development of the Russian 
Federation on April 14, 2014 № $26 \mathrm{P}^{\mathrm{A}} \mathrm{AY}^{1}$, certain methodological recommendations for the implementation of project management have been approved.

According to Paragraph 1.3 of the recommendations, the objectives of project management implementation, among others, are to ensure that results are achieved and improve the efficiency of resource use and intra-, interagency and inter-level interaction through the use of unified project management approaches.

In order to improve the activities on the strategic development of the Russian Federation and the implementation of priority projects, the President of Russia signed the Executive Order On the Presidential Council for Strategic Development and Priority Projects ${ }^{2}$. As part of its implementation, the Russian Government's Resolution On the Organization of Project Activities in the Government of the Russian Federation (combined with the Regulations on the Organization of Project Activities in the Government of the Russian Federation) of October 15, 2016 № 1050 was developed. To date, the Resolution has expired.

Strategic development directions were then identified and a list of national projects was approved, for which federal projects were identified. Regional projects are a project mechanism for achieving the goals of federal projects as components of national projects at the level of the Russian Federation subject.

According to I.I. Mazur and V.D. Shapiro, "Project management is a methodology of... organization, planning, management, coordination of labor... resources to effectively achieve its goals through modern methods... to achieve the results in the project" ${ }^{3}$.

\footnotetext{
${ }^{1}$ Instruction of the Ministry of Economic Development of the Russian Federation of April 14, 2014 № 26P-AY, On the Approval of the Guidelines for the Introduction of Project Management in the Executive Branch. (In Russ.) URL: http://www.consultant.ru/

${ }^{2}$ Executive Order of the RF President On the Presidential Council for Strategic Development and Priority Projects of June 30, 2016 № 306. (In Russ.) URL: http://www.consultant.ru/

${ }^{3}$ Mazur I.I., Shapiro V.D. (eds). Upravlenie proektami: ucheb. posobie dlya studentov, obuchayushchikhsya po spetsial'nosti Menedzhment organizatsii. 6-e izd [Project management: a tutorial. 6th edition]. Moscow, Omega-L Publ., 2010, p. 27.
}

The same source discusses the organization's transition to project management: "The implementation of the project should allow to practically solve the problem of transition to a project-oriented form of project management". To do this, systemic measures such as the creation of new structures (adaptation of the existing ones), development of a functioning mechanism, staff training, legal regulation, and the informatization of management should be implemented. It should be noted that staff training is an important part of this process and deserves to be considered separately.

In 2018, the methodological guidelines on regional project design were approved (according to Letter of the Executive Office of the Government of the Russian Federation of November 30, 2018 № 9861-П-П6) ${ }^{4}$. In accordance with these recommendations, the Head of the executive authority of the RF subject or respective Deputy are to be considered the Project Executive, and the Head of the structural unit of the executive authority of the RF subject or respective Deputy are to be considered the Project Manager (Paragraph 4).

The process of developing and implementing regional projects is based on the principles of project management methodology and standards governing project management, including GOST R 52807-2007 Guidelines for Evaluating the Competence of Project Managers ${ }^{5}$ and GOST R ISO 21500-2014 Guidelines for Project Management ${ }^{6}$.

\footnotetext{
${ }^{4}$ Methodological Guidelines on Regional Project Design of November 30, 2018 № 9861п-П6. (In Russ.) URL: https://sev.gov.ru/goverment/ispolnenie-ukazov/strategy/npa/

${ }^{5}$ GOST R 52807-2007. National Standard of the Russian Federation, Guidelines for Evaluating the Competence of Project Managers, as approved and enacted by Order of the Federal Agency on Technical Regulating and Metrology of December 27, 2007 № 423-ст, from Sectoral Technical Standards data base. (In Russ.) URL: http://www.consultant.ru/

${ }^{6}$ GOST R ISO 21500-2014. National Standard of the Russian Federation, Guidelines for Project Management, as approved and enacted by Order of the Federal Agency on Technical Regulating and Metrology of November 26, 2014 № 1873-ст, from Sectoral Technical Standards data base. The Guidelines were designed to formulate regional projects to achieve the goals, indicators and results of federal projects included in the national projects defined by the RF President's Executive Order On National Goals and Strategic Objectives of the Russian Federation through to 2024 of May 7, 2018 № 204. (In Russ.) URL: http://www.consultant.ru/
} 
According to GOST R ISO 21500-2014, the organizations' top executives and project officersin-charge are the targeted audience ${ }^{7}$. Areas of application of the Standard are organizations of ...any type, including public ones,.. with respect to projects of all kinds, regardless of their complexity, scope or duration ${ }^{8}$. Section 4.3 .15 of the document reads the following: The purpose of forming a project team is to provide the project with human resources... The manager should take into account various factors such as the knowledge and experience of candidates, their personal characteristics, as well as the group dynamics ${ }^{9}$. According to Section 4.3 .18 of the document, the goal of the project team development is to continuously increase professionalism and improve the interaction between team members, aimed at increasing the level of motivation and effectiveness of collaboration $^{10}$.

GOST R 52807-2007 sets the project managers' competency requirements, provides a framework for determining the level of competence... It can be applied as a model used to establish fundamental requirements ${ }^{11}$.

This Standard uses the following components of competence:

- areas of competence that determine professional spheres where the competence of the specialist must be confirmed;

- competence criteria that set the performance and/or characteristics of competence required for each particular element of competence ${ }^{12}$.

They determine the results of practical activities that a specialist must demonstrate in each element of competence. On the basis of this, a conclusion on the specialist's competence is made.
Areas of competence complement the specialist's competence criteria by clarifying critical and/or important aspects of his/her competence criteria and their applying. According to this Standard, competence elements in the project management (OK $2^{13}$ Appointment of Staff with the Appropriate Competence Required to Implement the Project), among others, are as follows: Specifying the Project Single Roles and Ensuring Concerted Efforts ${ }^{14}$.

Paragraph 5 Regional Project Certificate of the Methodological Guidelines on Regional Project Design defines project roles. Public civil servants, government employees of the executive authorities are the project executives, managers, parties, and participants. They are qualified in order to fill public civil service posts.

According to the Methodological Tools for Setting Qualification Requirements to Civil Service Candidates. Version 3.2, professional and functional qualification requirements are the requirements for specialties, vocational education training programs, knowledge and skills to fill a civil service position, depending on the area and type of activities and taking into account functional responsibilities ${ }^{15}$.

Professional qualifications are the requirements for specialty (training program), relevant professional experience, training area, professional knowledge and skills necessary for the performance of official duties in the area and type of activity.

Functional qualifications are the knowledge and skills requirements, depending on functional responsibilities in the area and activities (regulatory and public policy-making, monitoring activities, public services, etc. $)^{16}$.

The content analysis of these sources indicates a commonality of the concepts and categories that are governed by project management standards

\footnotetext{
${ }^{13}$ Non-Technical Skills. (Editor's note).

${ }^{14}$ GOST R 52807-2007. National Standard of the Russian Federation, Guidelines for Evaluating the Competence of Project Managers, p. 8.

${ }^{15}$ Methodological Tools for Setting Qualification Requirements to Civil Service Candidates. Version 3.2, as approved by the Ministry of Labor and Social Protection of the Russian Federation. (In Russ.) URL: http://www.consultant.ru/

${ }^{16}$ Ibid. P. 5.
} 
and guidelines for setting qualifications. Thus, high requirements are specified to form project teams for the development and implementation of regional projects to ensure that the competencies of all project participants meet the project goals and objectives.

In this regard, it is necessary to analyze the state of preparedness of the system of executive authorities of the subjects of the Russian Federation to implement the project-based approach in terms of its personnel component.

At the moment, there are certain results of such an assessment already. For instance, in 2018, the Krasnoyarsk Economic Forum summarized preliminary results of the Project Activity Index evaluation. It is a relatively new tool for measuring the efficiency of executive authority systems in managing project activities ${ }^{17}$. It was proposed by the Federal Office for Project Management.

According to the Project Management Center at the RANEPA ${ }^{18}$ data, the Belgorod Oblast is the leading region in this respect ${ }^{19}$.

As V.N. Leksin and B.N. Porfiryev point out, it is the region where ...by coordinating the actions... of project parties... the work performance has improved significantly and the implementation time has been reduced by 20 to 50 percent [1, p. 15].

\section{Research materials and methods}

The introduction of the project-based approach in the activities of the authorities in the pilot regions

\footnotetext{
${ }^{17}$ The official website of the Krasnoyarsk Economic Forum: Russia 2018-2024: Reaching the Potential.

URL: http://www.krasnoforum.ru/program/indeks-proektnojdeyatelnosti-kak-instrument-izmereniya-effektivnosti-organovvlasti/

${ }^{18}$ Project Management Center at the RANEPA. URL: https://pm.center/company/news/predvaritelnye-itogiotsenki-indeksa-proektnoy-deyatelnosti-po-regionam-predstavilina-krasnoyarskom/

${ }^{19}$ The Belgorod Oblast ranks first in the Top 5 Leading Regions in the Project Activity Index Pilot Group, Top 5 Leading Regions by Project Promotion Management Index, Top 5 Leading Regions by Decision-Making and Institutional Support Index, Top 5 Leading Regions by Project Management Index, and it ranks second in the Top 5 Leading Regions by Strategic Planning and Project Portfolio Management Index and Top 5 Leading Regions by Competence Development and Performance Culture Index.
}

has had a positive impact on their investment climate ${ }^{20}$.

For instance, S.A. Kozhevnikov shows the effect of the approach introduction in the Belgorod Oblast [2], and D.G. Krasil'nikov and M.N. Yakimova are considering the practices of using the project management by the executive authorities of the Perm Krai [3].

It is worth noting that the project-based approach can be applied in different ways. For instance, I.S. Bagdasar'yan speaks about the importance of project management [4]. A.I. Galimova and D.M. Malikova talk about the introduction of project management as a tool to improve the efficiency of the State executive authorities [5]. F.M. Opochinskii analyzes the positive effects of its introduction in the Federal subjects of Russia [6]. S.A. Kozhevnikov identifies a list of activities that contribute to the enabling environment for the project-based approach [7]. G.V. Lekarev and I.V. Baranova consider the functioning of systems of motivation of government employees in the sphere of project management in the subjects of the Russian Federation ${ }^{21}$. D.V. Nekhaichuk, Yu.S. Nekhaichuk and A.I. Karlova discuss one of the main advantages of the project-based approach, namely, the effective interaction of economic actors [8]. T.A. Filyakova focuses on the main benefits of the project-based approach to the formation of the digital economy in the region ${ }^{22}$.

\footnotetext{
${ }^{20}$ The list of pilot regions included the Belgorod, Yaroslavl and Penza Oblasts, and the Perm Krai.

${ }^{21}$ Lekarev G.V., Baranova I.V. [Motivation of government employees in the field of project management as an instrument to increase the efficiency of executive bodies' activity]. Nepreryvnoe professional'noe obrazovanie: teoriya i praktika: sbornik nauchnykh statei po materialam IX Mezhdunarodnoi nauchnoprakticheskoi konferentsii prepodavatelei, aspirantov, magistrantov i studentov [Proc. 9th Int. Sci. Pract. Conf. of Teachers, Graduate Students, Undergraduates and Students: Continuing Professional Education: Theory and Practice]. Novosibirsk, Siberian Academy of Finance and Banking Publ., 2018, pp. 24-29. (In Russ.)

${ }^{22}$ Filyakova T.A. [Project management and the digital economy of the region]. Arrigievskie chteniya po teme: Formirovanie novoi paradigmy ekonomicheskogo myshleniya XXI veka: Materialy Mezhdunarodnoi nauchno-prakticheskoi konferentsii [Proc. Int. Sci. Pract. Conf. Arrighi Readings: The Formation of a New Paradigm of Economic Thinking in the 21st Century]. Orel, Orel State University named after I.S. Turgenev Publ., 2018, pp. 319-322. (In Russ.)
} 
Taking into account all the significant advantages that a particular region gains during the implementation of a particular project and further on, as well, it is necessary to point out the factors that either reduce the region's development rate in this direction, i.e. deter the project-based approach implementation, or make the project less effective.

A.B. Tlisov and N.N. Kiseleva express the opinion that regions are not ready to provide quality support for the process of introducing project management into the activities of the subjects' executive authorities as there is a lack of knowledge and skills in the field of project management... [9, p. 54].

D.S. Shtreis notes such a factor as a lack of interagency interaction and inter-industry relations $[10$, p. 210].

M.N. Yakimova and D.G. Krasil'nikov emphasize the bureaucratic nature of the institutional environment of the structures implementing public policy [11, p. 389]. Their other joint paper qualifies a strict organizational structure of the authorities, insufficient use of specialized information systems for project management, the difficulty of assessing the results of the projects implemented, and the design of ongoing activities in the form of projects as the key factors of project management distortion [12].

A.S. Mukhametshina and A.O. Gomaleev consider the number of public servants involved in the project activities an important factor. They note that in 2018, only one specialist from the Kaluga Oblast was included in the Single State Register of Project Specialists in the Public Sector of the Russian Federation [13].

Based on a survey of civil servants of the Novgorod Oblast, I.A. Ratkovskaya and O.D. Pritula identified the factors, among others, of lack of necessary knowledge and skills in the field of project management [14, p. 113].

I.A. Kuznetsov points out the fact that employees do not always clearly understand and share the view concerning the nature of the project-based approach... a number of key decisions remain on paper [15, p. 9].
L.A. Ramenskaya notes the general uneven development of project management in the regions [16].

Within the implementation of the Regulations on the Organization of Project Activities in the Government and Executive Authorities of the Russian Federation ${ }^{23}$, the competences and training systems of public civil servants, linked to the similar models developed in the regions, should be established. These models are freely available, for example on the official websites of the Shebalinsky District of the Altai Republic, the Murmansk Regional Government, the Autonomous Educational Institution of the Khanty-Mansi Autonomous Okrug - Yugra Regional Institute for Administration.

The competency-based approach and competency model should be used due to current transformations, which make companies renew or train their personnel or teach the existing personnel to acquire new knowledge and skills.

The competency model for civil servants of specialized executive authorities in the Murmansk Oblast and employees of specialized organizations working to lure investments provides for graders of efficiency and competency criteria, and criteria of the resultoriented focus, team work, self-development, management of activities and effective communication by group of positions (from junior through senior).

Evaluating the model, we note that it fails to give complete account of personnel development issues since the document views training solely in terms of self-development, while experience is considered in terms of learning, teaching and dissemination of knowledge, skills and reference to practices of other regions and projects.

In the mean time, other sources mention that the implementation of effective mechanisms for civil

\footnotetext{
${ }^{23}$ Resolution of the Government of the Russian Federation On the Organization of Project Activities in the Government of the Russian Federation (combined with the Regulations on the Organization of Project Activities in the Government of the Russian Federation) of October 31, 2018 № 1288 (as amended on January 3, 2019). URL:

http://www.consultant.ru/document/cons_doc_LAW_310151/
} 
service of high professionals is one of the crucial priorities outlined in the national policy ${ }^{24}$.

As N.V. Globenko and N.E. Udalova put it, the model should define competencies that accommodate the regional specifics and help determine what knowledge, skills and values civil servants should have [17, p. 2]. We cannot but agree with the opinion.

Therefore, as part of the project-based approach, it is reasonable to give a more thorough consideration to related factors of HR policy that make executive authorities fit for the projectbased approach. We denote them as the $H R$ factor.

Staff turnover is one of the most considerable factors. The personnel constitutes one of the most valuable assets of any organization, with governmental authorities being no exception.

However, the efficacy and performance depend not only on the quality of work they perform, but also on the efficiency of the HR management system. The organization should not only build a team of promising professional personalities, but also make it sustainable. Otherwise, the team will not meet qualification and professional criteria for the project, thus undermining the efficacy of any endeavors.

Any staff moves should be sound and reasonable, considering that the project environment... may be exposed to changes, and appropriate team members may be selected throughout the entire project life ${ }^{25}$.

What does matter is the extent to which the above professional and qualification requirements meet The Methodological Tools for Setting Qualification Requirements to Civil Servants. Version $3.2^{26}$. Candidates shall be compliant with

\footnotetext{
${ }^{24}$ Methodological Guidelines, The Model for Professional Competence of Civil Servants in the Khanty-Mansi Autonomous Okrug - Yugra. Khanty-Mansiysk, Regional Institute for Administration Publ., 2014, 142 p. (In Russ.) URL: https://adminugra.ru/

${ }^{25}$ GOST R ISO 21500-2014. National Standard of the Russian Federation, Guidelines for Project Management, as approved and enacted by Order of the Federal Agency on Technical Regulating and Metrology of November 26, 2014 № 1873-ст, from Sectoral Technical Standards data base.

${ }^{26}$ Methodological Tools for Setting Qualification Requirements
} to Civil Service Candidates. Version 3.2. the respective requirements, with the relevant higher professional education being a primary grader. Furthermore, the vacancy description indicates both duties and principal requirements, i.e. aspects to be analyzed additionally.

We suggest reviewing the factor, referring to the executive authority of the Nizhny Novgorod Oblast. As per Paragraph 2, Article 1 of Law of the Nizhny Novgorod Oblast of December 30, 2005 № 225-3, On Civil Service Positions in the Nizhny Novgorod Oblast and Register of Civil Service Positions in the Nizhny Novgorod Oblast $^{27}$, civil service positions are established by the Charter and local laws in accordance with the list of standard civil service positions existing in the subjects of the Russian Federation as approved by the President of the Russian Federation.

To illustrate this, let us refer to the position of the senior specialist in a department.

As per the above Register, it is attributed to the senior group (Group 2), Class Specialists (Register No. C03201). Paragraph 2 of the Qualification Requirements of the Personnel Regulations governing the basic requirements put it as 1.1. Professional Education: Higher Education; 1.2. Record of Civil Service or Professional Record are not subject to any criteria. As for professional and functional requirements to the candidate's qualification, it does not specify what discipline the candidate shall major in professionally. It is noteworthy that the regulations do not indicate what relevant experience or education the candidate shall have with reference to the position he or she aspires to take. This is quite disturbing as it may worsen or undermine the efficiency of interaction among project teams or team members. Furthermore, GOST R 52807-2007 (Table 5 Elements of Project Management Competence) for competency OK2 qualifies Ensuring smooth operations as one of such elements and indicates the following criteria: 2.1 The project team operates smoothly; 2.2 Expectations about the team behavior are identified and agreed by

\footnotetext{
${ }^{27}$ Law of the Nizhny Novgorod Oblast On Civil Service Positions in the Nizhny Novgorod Oblast and Register of Civil Service Positions in the Nizhny Novgorod Oblast of December 30, 2005 № $225-3$.
} 
relevant parties; 2.3 The team performance is controlled, with the respective feedback being given $^{28}$.

Project thinking is another factor arising from project management. T.V. Uskova and E.D. Kopytova, researchers from the Institute for Socio-Economic Development of Territories of the Russian Academy of Sciences, point out that managers lack necessary skills and have insufficient knowledge and competence [18], thus necessitating the cultivation and development of project thinking.

Currently, we observe the predominance of a new type of managers who may have no special professional credentials, but have already proved their effective performance. However, it is reasonable to ask whether all segments should be treated equally since each of them is distinct. Consequently, it is difficult for a project stakeholder to fairly evaluate the attainability of goals and results in some segment in comparison with the other unknown one, relying simply on the previous similar experience.

\section{Results}

To make judgment whether the educational background meets the position of a civil servant, we refer to publicly available data on official websites of the capitals of the Russian Federal Districts. Based on the information, we performed a content analysis of administrative authorities of each subject.

To streamline and substantiate our conclusions, we grouped analyzable parameters into input tables, indicating the position, education (university and profession) and previous professional track record of a civil servant. We found out that positions and occupation were found to disaccord with professional and functional requirements.

Some websites (for instance, almost all the ministries of the Sverdlovsk Oblast) depict the structure of the ministries, contacts or duties as

\footnotetext{
${ }^{28}$ GOST R 52807-2007. National Standard of the Russian Federation, Guidelines for Evaluating the Competence of Project Managers, as approved and enacted by Order of the Federal Agency on Technical Regulating and Metrology of December 27, 2007 № 423-ст, from Sectoral Technical Standards data base. (In Russ.) URL: http://www.consultant.ru/
}

additional information. Furthermore, some websites publish details of ministers for culture, physical culture, sports, youth policy and healthcare whose education and training completely match their positions.

The same is true for departments. There is no information about the top management on official websites of departments for IT and communications, public housing and construction oversight, public procurement, protection, control and regulation of the fauna use, labor and employment and ensuring the performance of justices of peace. In the mean time, there are publicly available information about the director of the veterinary department whose education and professional track record satisfy the criteria set completely.

The page Personnel on the website, Open Government of the Sverdlovsk Oblast ${ }^{29}$, shows members of the government, executive and municipal authorities. The account of each position should specify certain parameters, such as specialization, education, professional experience, active/inactive status, including the examination of documents and contribution to discussions of priorities and indicators. However, such information is missing, except for initials and the position.

We should make a special mention on the Government of the Novosibirsk Oblast. Its official website $^{30}$ does not present any information about top persons of the Ministry for Industry, Trade and Entrepreneurship Development, Ministry for Healthcare, Ministry for Labor and Social Development, Ministry for Construction and Department for Tariffs, governmental inspection for housing, department for information projects and department for governance of justices of peace. However, we found the total correlation of the educational background and the position occupied by most leaders, including ministers of justice, physical culture and sports, natural resources and ecology, education, culture, science and innovative policy, agriculture, transport and road systems, economic

\footnotetext{
${ }^{29}$ Web portal Open Government of the Sverdlovsk Oblast. (In Russ.) URL: http://open.midural.ru/

${ }^{30}$ Government of the Novosibirsk Oblast. (In Russ.) URL: https://www.nso.ru/
} 
development, housing and utilities, power engineering, and heads of some inspectorates, departments and administrations.

Having analyzed the website of the Government of the Stavropol Krai ${ }^{31}$, we noted that heads of the ministries for road systems and transport, finance and physical culture and sports meet requirements to the educational background and work experience. There is no information about heads of other ministries.

Relying on the data, we conclude that top persons of executive authorities in the subjects of the Russian Federation are not required to have relevant education in line with their activities. In most cases, their educational background mismatches the criteria (with just a few exceptional cases). Decisions on the implementation of some project are made in accordance with views of a certain official, profession and relevant experience, even if it has other sectoral and (or) professional focus.

This may trigger higher risks because the planned project will not allow to solve the most vital and priority issues of spatial socio-economic development as effectively as possible, thus consequently affecting the efficiency of budgetary spending.

\section{Conclusions}

The issue herein becomes even more important as Vladimir Putin, the Russian President, mentioned the efficiency of human resources during his address to the Federal Assembly in February 2019, saying that the work of the executive branch at all levels should be coordinated, meaningful and energetic... ${ }^{32}$, ...all those who work in the social sphere or join the government or municipal services in order to help people resolve their urgent problems, must meet the highest professional standards... ${ }^{33}$.

Analyzing publicly available data on professional, functional and qualification

\footnotetext{
${ }^{31}$ Web portal of executive authorities of the Stavropol Krai. (In Russ.) URL: http://www.stavregion.ru/

${ }^{32}$ Presidential Address to the Federal Assembly, February 20, 2019. (In Russ.) URL:

http://en.kremlin.ru/events/president/transcripts/messages/59863

${ }^{33}$ Ibid.
}

standards of high-ranking officials working in ministries of the executive branch throughout the subjects of the Russian Federation, we can summarize and infer the statements below.

1. In most cases, civil servants' education does not correspond with the position they occupy.

2. In some cases, a person does not have professional training but demonstrates good (active) professional advancement and career progression.

3. Despite having no special professional credentials, sometimes a person has relevant professional experience.

In this conclusion, we emphasize that civil servants in executive authorities of the subjects of the Russian Federation should be additionally trained to master and acquire necessary knowledge of project management or certified respectively. 


\section{References}

1. Leksin V.N., Porfiryev B.N. [Issues and perspectives of using project-oriented approach in the Russian Arctic development management policy]. MIR (Modernizatsiya. Innovatsii. Razvitie) = MIR (Modernization. Innovation. Research), 2015, vol. 6, no. 4(24), pp. 10-18. (In Russ.) URL: https://doi.org/10.18184/2079-4665.2015.6.4.10.18

2. Kozhevnikov S.A. [Gaining Efficiency of Public Administration - Key Objective for Modern Russia]. Ekonomicheskie i sotsial'nye peremeny: fakty, tendentsii, prognoz = Economic and Social Changes: Facts, Trends, Forecast, 2017, vol. 10, no. 3, pp. 78-99.

URL: https://cyberleninka.ru/article/n/povyshenie-effektivnosti-gosudarstvennogo-upravleniyaklyuchevaya-zadacha-dlya-sovremennoy-rossii (In Russ.)

3. Krasil'nikov D.G., Yakimova M.N. Ob urovne razvitiya protsessov upravleniya proektami $v$ ispolnitel'nykh organakh gosudarstvennoi vlasti Permskogo kraya. V kn.: Strategicheskoe i proektnoe upravlenie. Sbornik nauchnykh statei [On the level of development of project management processes in the executive bodies of the State government of the Perm Krai. In: Strategic and project management: A collection of scientific articles]. Perm, Perm State National Research University Publ., 2011, pp. 69-75.

4. Bagdasar'yan I.S. Proektnoe upravlenie v sotsial'no-ekonomicheskom razvitii Rossii. V kn.: Ekonomicheskii rost: faktory effektivnogo razvitiya [Project Management in Russia's Social and Economic Development. In: Economic Growth: Factors of Effective Development]. Penza, Nauka i prosveshchenie Publ., 2017, pp. 31-37.

5. Galimova A.I., Malikova D.M. [Project management as a tool of increase of efficiency of activity of bodies of State executive power]. Sotsial'no-ekonomicheskoe upravlenie: teoriya i praktika $=$ Socio-Economic Management: Theory and Practice, 2017, no. 1(30), pp. 15-17. URL: https://istu.ru/material/images/izdat/soc/2017/1/2017-1-galimova.pdf (In Russ.)

6. Opochinskii F.M. [Analysis of expectations from the implementation of project management in authorities]. InnoTsentr, 2018, no. 2(19), pp. 19-26. (In Russ.)

7. Kozhevnikov S.A. [Project management as a tool for enhancing the performance of government executive bodies]. Voprosy territorial'nogo razvitiya $=$ Territorial Development Issues, 2016, no. 5(35), pp. 1-17. URL: https://cyberleninka.ru/article/n/proektnoe-upravlenie-kak-instrumentpovysheniya-effektivnosti-deyatelnosti-organov-gosudarstvennoy-ispolnitelnoy-vlasti (In Russ.)

8. Nekhaichuk D.V., Nekhaichuk Yu.S., Karlova A.I. [The project management as a tool to increase the efficiency of State executive bodies]. Ekonomika i predprinimatel'stvo = Journal of Economy and Entrepreneurship, 2019, no. 1(102), pp. 804-808. (In Russ.)

9. Tlisov A.B., Kiseleva N.N. [Introduction of project management in activity of authorities of the region as the mechanism of increase in its investment appeal]. Upravlencheskoe konsul'tirovanie $=$ Administrative Consulting, 2016, no. 12, pp. 49-54.

URL: https://cyberleninka.ru/article/n/vnedrenie-proektnogo-upravleniya-v-deyatelnost-organovvlasti-regiona-kak-mehanizm-povysheniya-ego-investitsionnoy-privlekatelnosti (In Russ.)

10. Shtreis D.S. [Prospects for the introduction of project management in implementation of State programs]. Vestnik Novgorodskogo filiala RANKhiGS $=$ Bulletin of Novgorod Branch of RANEPA, 2016, vol. 1, no. 5-1, pp. 209-218. (In Russ.)

11. Yakimova M.N., Krasil'nikov D.G. [Specificity of a State administrative sphere project]. Ars Administrandi, 2018, vol. 10, no. 3, pp. 380-395.

URL: http://ars-administrandi.com/article/2018_3-380-395.pdf (In Russ.) 
12. Krasil'nikov D.G., Yakimova M.N. [Projekt management deformation factors in State government bodies (exemplified by State policy implementation in modern Russia)]. Ars Administrandi, 2015, no. 2, pp. 36-48. URL: https://cyberleninka.ru/article/n/faktory-deformatsii-proektnogoupravleniya-v-organah-gosudarstvennoy-vlasti-iz-opyta-realizatsii-gosudarstvennoy-politiki-v (In Russ.)

13. Mukhametshina A.S., Gomaleev A.O. [Implementation of project management in the public authorities of the Kaluga Oblast]. Alleya nauki, 2018, vol. 1, no. 10, pp. 765-768. (In Russ.) URL: https://alley-science.ru/domains_data/files/NovJournal18/1_TOM_noyabr.pdf

14. Ratkovskaya I.A., Pritula O.D. [Development of the personnel potential of civil servants of the Novgorod Oblast in project management implementation]. Vestnik Novgorodskogo filiala RANKhiGS = Bulletin of Novgorod Branch of RANEPA, 2017, vol. 6, no. 2, pp. 110-117. (In Russ.)

15. Kuznetsov I.A. [Project-based approach in managing socio-economic development of the region]. Voprosy territorial'nogo razvitiya = Territorial Development Issues, 2018, no. 4(44), pp. 1-12. URL: http://noc.isert-ran.ru/files/journal/issues/vtr-2018-4-44-9ad646ec23--ru.pdf (In Russ.)

16. Ramenskaya L.A. [Special features of regional level public project management]. Fundamental'nye issledovaniya $=$ Fundamental Research, 2018, no. 1, pp. 111-115. URL: http://fundamental-research.ru/ru/article/view?id=42059 (In Russ.)

17. Globenko N.V., Udalova N.E. [Model of competencies and the system of training of State civil servants executing duties on project management in the Voronezh region]. Region: gosudarstvennoe i munitsipal'noe upravlenie, 2017, no. 4(12), pp. 1-15. (In Russ.) URL: http://regiongmu.ru/wp-content/uploads/2018/01/RegionGMU0804012.pdf

18. Uskova T.V., Kopytova E.D. [On the Issues of Implementation of Project Management in the Bodies of Authority]. Problemy razvitiya territorii = Problems of Territory's Development, 2017, no. 4(90), pp. 7-27. URL: https://cyberleninka.ru/article/n/k-voprosu-o-vnedrenii-proektnogoupravleniya-v-organah-vlasti (In Russ.)

\section{Conflict-of-interest notification}

We, the authors of this article, bindingly and explicitly declare of the partial and total lack of actual or potential conflict of interest with any other third party whatsoever, which may arise as a result of the publication of this article. This statement relates to the study, data collection and interpretation, writing and preparation of the article, and the decision to submit the manuscript for publication. 